\title{
RBM15/MKL1 Fusion Protein
}

National Cancer Institute

\section{Source}

National Cancer Institute. RBM15/MKL1 Fusion Protein. NCI Thesaurus. Code C99702.

A fusion protein that is encoded by the RBM15/MKL1 fusion gene. This protein consists of most of the putative RNA-binding protein 15, including the RNA recog nition motifs and the SPOC domain, fused to most of the MKL/myocardin-like protein 1, including the scaffold attachment factor box. 